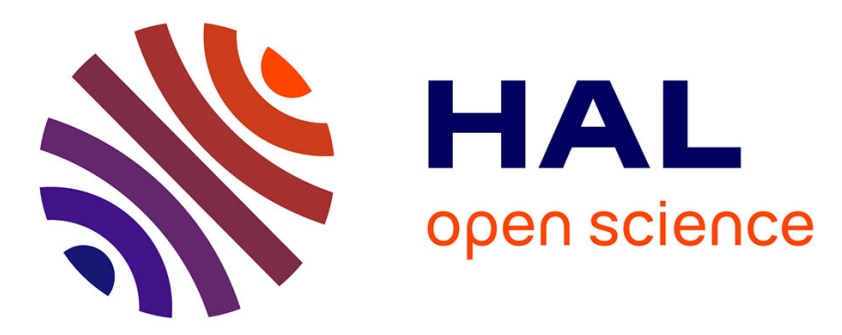

\title{
Developmental processes and motivations for linkages in cross-sectoral sport clusters
}

\author{
Anna Gerke, Kathy Babiak, Geoff Dickson, Michel Desbordes
}

\section{To cite this version:}

Anna Gerke, Kathy Babiak, Geoff Dickson, Michel Desbordes. Developmental processes and motivations for linkages in cross-sectoral sport clusters. Sport Management Review, 2017, 21 (2), pp.133-146. 10.1016/j.smr.2017.05.005 . hal-01666875

\section{HAL Id: hal-01666875 https://hal.science/hal-01666875}

Submitted on 24 Apr 2018

HAL is a multi-disciplinary open access archive for the deposit and dissemination of scientific research documents, whether they are published or not. The documents may come from teaching and research institutions in France or abroad, or from public or private research centers.
L'archive ouverte pluridisciplinaire HAL, est destinée au dépôt et à la diffusion de documents scientifiques de niveau recherche, publiés ou non, émanant des établissements d'enseignement et de recherche français ou étrangers, des laboratoires publics ou privés. 


\title{
Title
}

Developmental processes and motivations for linkages in cross-sectoral sport clusters

\author{
Authors \\ Anna Gerke, Audencia Business School, France \\ Kathy Babiak, University of Michigan, USA \\ Geoff Dickson, Auckland University of Technology, New Zealand \\ Michel Desbordes, Université Paris-Sud, France
}

\begin{abstract}
Interorganisational linkages are a widely studied topic in sport management. However, most researchers focus on public or non-profit organisations and analyse one focal organisation rather than a network of interrelated organisations. The purpose of this study was to address both of these shortcomings by investigating interorganisational linkages in sport clusters, a type of crosssectoral network. The authors address three main questions: (a) what is the nature of interorganisational linkages in sport clusters; (b) how do linkages in sport clusters develop; and (c) what are the organisational motivations for creating or joining linkages in sport clusters? A multiple case study approach explores two sailing clusters in France and New Zealand. Results show that interorganisational relationships tend to be formalised, while interorganisational networks tend to be informal. A circular development process from formal relationships to formal networks via informal relationships and networks was detected. Reciprocity is the most prevalent motive for the development of all types of interorganisational linkages. This research contributes to sport management practice by showcasing the potential multitude and variety of
\end{abstract}


interorganisational linkages in a cross-sectoral sport context which are foundations for cooperation and collaboration. The theoretical contribution lies in the conceptualising of the IOR development process and different motivational patterns as antecedents.

Key words: interorganisational relationships; interorganisational networks; sport cluster; crosssectoral 


\section{Introduction}

Sport systems are complex and often vary in form, structure, and purpose across different countries. The actors within sport systems typically include for-profit organisations (e.g., sport equipment firms), non-profit organisations (e.g., amateur sport clubs), public organisations (e.g., Ministries of Sport), governing bodies (e.g., national sport federation), and unorganised stakeholders (e.g., customers of a sport brand) (Petry, Steinbach, \& Tokarski, 2004; Shilbury, 2000). Previous research on sport systems focuses on policy issues in elite and professional sports (De Bosscher, De Knop, van Bottenburg, Shibli, \& Bingham, 2009; Dickson, Arnold, \& Chalip, 2005; Dickson, Phelps, \& Waugh, 2010), governance aspects in non-profit sport organisations (Ferkins, Shilbury, \& McDonald, 2005; Inglis, 1997), or the increased professionalisation of nonprofit sport organisations (Macris \& Sam, 2014). Few sport management researchers have focused on the group of for-profit organisations that manufacture sport equipment despite their relevance to the development and commercialisation of sport (Slack \& Thurston, 2014).

While the literature on interorganisational relationships (IORs) in sport is growing (Misener \& Doherty, 2013; Wäsche, 2015), the scholarly focus has primarily been on discrete cases of focal organisations and their partners (Dickson, Arnold, \& Chalip, 2005; Frisby, Thibault, \& Kikulis, 2004). The management of linkages between organisations involved in sport is increasingly important and complex due to the heterogeneity of activities, goals, and outcomes. Researchers have examined the motives for IORs in cross-sector relationships in elite sport (e.g., access to resources, legitimacy seeking, reciprocity, and strategic positioning) and also in community sport development programs (Misener \& Doherty, 2013). Scholars have also explored the challenges of balancing competition and collaboration (Babiak, 2007; Babiak \& Thibault, 2009; Marlier et al., 2015). Other researchers have focused on IORs and key management 
practices in professional sport (Cousens, Babiak, \& Slack, 2000), across municipal recreation organisations (Frisby et al., 2004), or in the context of sport organisations and corporate sponsors (Bee \& Kahle, 2006; Benijts, Lagae, \& Vanclooster, 2011; Cousens, Babiak, \& Bradish, 2006). Recently, sport management researchers have examined IORs and cooperation in sport tourism networks, and in these networks, a central organisation (i.e., tourism organisation) was the pivotal actor of the network (Wäsche, 2015; Wäsche \& Woll, 2010)

In this study, we investigate interorganisational linkages in a different interorganisational configuration - sport clusters - and discuss stakeholder motives for creating or joining IORs in these clusters. The cluster concept refers to a well-established field of research which Marshall (1920) pioneered with his work on industrial districts. Porter (2008) coined the modern understanding and use of clusters not only in research but also in national and regional economic policies. Sport clusters represent "all organisations and industries in a particular geographical area that have an interest in the same sport or related sports as either buyer or seller" (Gerke, Desbordes, \& Dickson, 2015, p. 3). In other words, sport clusters are localised systems of production and demand around a sport or related sports including a mix of for-profit, non-profit, public organisations, and governing bodies (Gerke et al., 2015). While there is a growing body of research on IORs in the sport management field (Babiak, 2007; Babiak \& Thibault, 2009; Babiak \& Willem; 2016), there is little in the way of exploration of interorganisational linkages in sport clusters (Kellett \& Russell, 2009).

Organisations in sport clusters studied here include companies providing equipment (e.g., core equipment manufacturers, systems suppliers, or accessory suppliers), services, media, or designs. These clusters also include professional and amateur sport organisations (non-profit organisations), governing bodies, and education/research institutes (public organisations) (Gerke 
et al., 2015). Given that collaboration plays a central role in the delivery of activities produced by different cluster members, a deeper understanding of the drivers to this form of structuring merits further investigation. To that end, in this study, we address three main questions: (a) what is the nature of interorganisational linkages in sport clusters; (b) how do linkages in sport clusters develop; and (c) what are the organisational motivations for creating or joining linkages in sport clusters?

\section{Conceptual Framing of Interorganisational Linkages}

IORs are established through interactions or transactions between two organisations with the common aim of serving mutually beneficial purposes (Babiak, 2007; Oliver, 1990). The simplest IOR is an economic transaction; however, this type of IOR is rarely subject to IOR research. We acknowledge simple transactional IORs as a first level of relationships, and focus on repeated or regular interactions between the same parties (transactional or other) that are based on trust and collaboration aiming at mutually beneficial purposes.

Interorganisational networks (IONs) develop as soon as two IORs are linked; hence, three or more organisations are involved (Dickson, Arnold \& Chalip, 2005; Provan, Fish, \& Sydow, 2007). Similar to IORs, the simplest form of IONs is based on economic transactions. However, also in terms of ION, we focus on mid- or long-term, collaborative or cooperative, trust-based ION with a shared goal or mutual beneficial purposes (Wäsche \& Woll, 2010).

Most existing sport cluster studies simply apply Porter's (2008) cluster model to a sport context (Chetty, 2004; Stewart, Skinner, \& Edwards, 2008), while some develop the concept of a sport cluster (Gerke et al., 2015; Shilbury, 2000). However, all of these studies focus on determinants and features of cluster development rather than on dynamics and interactions between cluster members. This is where we extend knowledge on sport clusters. The 
geographical concentration of interconnected companies and associated institutions in one field -

usually denominated as industrial districts (Marshall, 1920) or clusters (Porter, 2008) - provides a rich empirical context to study IORs and IONs (Capo-Vicedo, Exposito-Langa, \& MolinaMorales, 2008; Connell \& Voola, 2013; Gomes \& Hurmelinna-Laukkanen, 2013).

\section{Formalisation of Interorganisational Linkages}

Interorganisational linkages are characterised by ambiguity and uncertainty due to different structures, cultures, functional capabilities, cognitive frames, terminologies, management styles, and philosophies. This is especially the case when organisations have different histories, belong to different industries, and possess dissimilar belief systems (Vlaar, Van den Bosch, \& Volberda, 2006). Dana and Granata (2013) argue that formalisation strengthens collaborations and creates a collaborative spirit. The formalisation of interorganisational linkages also reduces misunderstanding, especially in the formative stages (Vlaar et al., 2006). Gomes and Hurmelinna-Laukkanen (2013) argue that informal relationships between individuals and organisations will also strengthen a collaboration.

The level of IOR formalisation differs in terms of process and interaction outcomes. Interorganisational processes can be formalised through planning, projecting, codifying, and enforcing exchanges. The outcomes of formalisation are contracts, rules, procedures, and plans (Vlaar et al., 2006). It is not always the case that both processes and outcomes are formalised. In some cases, formalisation of linkages may create lock-in effects, preventing organisations from joining collective initiatives (Gadde, Huemer, \& Håkanssoinglis, 2003).

There may be unique insights into the nature and dynamics of interorganisational engagement in sport. We can glean interesting insights into sport management research in this area. For instance, some studies have explored the role and level of formalisation of IORs in the 
sport sector and have found that institutional pressures and changes in sport systems (e.g., shift of governmental funding for sports) have led to increases in the creation and formalisation of interorganisational linkages (Babiak, 2007; Shilbury, 2000). Additionally, challenges related to capacity (e.g., lack of human resources, collaborative systems, communication channels) may play a role in the implementation and formalisation of IORs for non-profit sport organisations engaging in cross-sector linkages (Babiak, 2007; Misener \& Doherty, 2013). Finally, people involved in sport tend to have similar beliefs and modes of functioning, and hence might not insist on the formalisation of interorganisational linkages, instead, relying on interpersonal trust and faith that the partners will uphold their relationship responsibilities (Allen, Drane, Byon, \& Mohn, 2010; Walters \& Anagnostopoulos, 2012).

\section{Development and Motives for Interorganisational Linkages}

Babiak (2007) investigated multiple motives for IOR formation amongst collaborating cross-sector organisations and found complex and interrelated drivers for partnership formation which mapped onto Oliver's (1990) analytical framework of IOR formation. Those factors were asymmetry, reciprocity, necessity, legitimacy, efficiency, and stability. These constructs were derived from theoretical explanations including institutional pressures, resource dependency, strategic management, power, and political forces. Given this theoretical breadth, we found Oliver's (1990) analytical framing to be a robust foundation from which to examine motives for IOR development in sport clusters. Motivations for creating or joining interorganisational linkages might influence the formalised nature (informal versus formal) and configuration (IOR versus ION) that linkages take. Therefore we analyse motivational patterns for IOR/ION formation with regards to their formalisation and configuration. 
The following paragraphs outline briefly Oliver's (1990) motivational factors. Asymmetry refers to the desire or potential to exercise power or control over another organisation and its resources (Babiak, 2007; Oliver, 1990). Asymmetry reflects a power-dominated approach to linkage formation. An organisation with an asymmetry motive considers its environment as unjust, unequal, manipulated, and full of information distortion, exploitation, coercion, and conflict. Therefore the only way to resolve the inequity is via power, control, and domination (Oliver, 1990). Reciprocity reflects the pursuit of collaborative advantage (Huxham \& Vangen, 2009). Organisations in alliances, partnerships, or networks work more effectively and efficiently than isolated counterparts (Babiak, 2007; Porter, 2008). An organisation seeking reciprocity pursues cooperation, collaboration, and coordination. The theory of collaborative advantage and relational strategy explains how joint efforts are superior to independent actions (Dyer \& Singh, 1998; Granovetter, 1985; Huxham \& Vangen, 2009). Necessity as motive is manifest when organisations create IORs to meet necessary legal or regulatory requirements. This becomes relevant in situations where organisations need to comply with certain rules and regulations. In some cases, it might be easier to build partnerships to governing bodies, industry association, or other regulatory bodies in order to comply with those regulations (Oliver, 1990). Efficiency refers to an organisation's attempts to improve its internal input/output ratio through collaborative activity. The efficiency motive might be driven by desires to increase buying power, consolidate, and maximise the use of resources, and achieve economies of scale (Babiak, 2007; Oliver, 1990). Stability is a motive for IORs for organisations that seek predictability and dependability of resource flows. Uncertainty of funding and the increased number of organisations providing the same or similar services encourage sport organisations to create long-term IORs (Babiak, 2007). Legitimacy is the final motive underpinning IORs. Organisations are exposed to external 
pressures - economic, social, or political - to which they need to respond to appear legitimate (Oliver, 1990). In the sport context it means that sport organisations engage in linkages to legitimise both organisational and collective goals (Babiak, 2007).

\section{Methods}

Case study research permits the creation of close links between science and reality, and a strong connection between theory, method, and data (Dubois \& Araujo, 2007). The multiple case study method permits theory development and enhances theories' robustness through literal replication (Eisenhardt, 1989; Yin, 2009). Two similar cases, a sailing cluster in France (SAILBRIT) and one in New Zealand (SAILAUCK), are the subject of this research. Cases are analysed in parallel according to research questions to strengthen findings rather than sequentially in order to deepen findings (Yin, 2009).

Data were collected using an abductive approach (Dubois \& Gadde, 2002). The abductive approach refers to a continuous interplay between theory and empirical data enacted by the researcher, moving between theory, data, and back to theory again (Dubois \& Gadde, 2002). Pierce's (1903, cited in Burks, 1946) theory of abduction puts forward abduction as the process that invents and discovers explanatory hypotheses concerning isolated phenomena rather than merely testing and establishing the explanatory value of hypotheses (induction) or developing measurable consequences for universal hypotheses (deduction).

\subsection{Research Context}

The research contexts were industrial agglomerations in a particular geographical area whose actors shared an interest in the same or similar sport(s). These sport clusters were chosen because their membership is diverse and organisational interconnectedness is high (Gerke et al., 2015, Shilbury, 2000). Both sailing clusters were comprised of interconnected organisations 
including product or service firms, professional racing teams, amateur sailing clubs, public organisations, governing bodies, and tertiary institutions. Organisations were selected according to the cluster member typology developed by Gerke et al. (2015).

Both clusters dispose of a high density of organisations in the same sport (i.e., sailing) in a specific geographically denominated area. Previous research has demonstrated that sailing clusters are relatively common (Chetty, 2004; Gerke et al, 2015; Glass \& Hayward, 2001; Sarvan et al., 2011). Other studies on sport clusters have examined industries in outdoor sports including horse-riding (Parker \& Beedell, 2010), skateboarding (Kellett \& Russell, 2009), and surfing (Stewart et al., 2008; Warren \& Gibson, 2013). While most sport cluster studies apply Porter's (2008) framework focusing on structure and features, this article investigates cluster dynamics. SAILBRIT is the sailing cluster located in southern Brittany in the northwest of France. SAILBRIT is comprised of about 110 affiliated cluster members (Eurolarge Innovation, 2016). There is a cluster governing body, which is primarily publicly funded. The governing body is responsible for the administration, promotion, and growth of SAILBRIT. Given the historical and cultural significance of sailing to Brittany, the sailing industry is economically important to the region. An important driver for the sailing industry was the local government's decision to invest in maritime infrastructure and to dedicate industrial space to the maritime industry.

SAILAUCK is the sailing cluster in Auckland, New Zealand. Most cluster organisations (CLORs) are located close to the marinas adjacent to the central business district. CLORs were not affiliated to a specific sailing governing body, but most were formally linked via a marine trade and export group, which consisted of approximately 450 members including other nonsailing marine businesses (i.e., fishing and kayaking) (NZ Marine, 2016). Sailing and ocean navigation is an integral cultural and social institution in New Zealand, given its island 
geography. Sailing is integrated in schools, social events, and is an important economic

contributor. Part of New Zealand's culture and education is to involve children in sailing courses, participate in leisure or competitive sailing, watch major sailing events, or work in the marine industry.

\subsection{Data Collection}

Four types of data sources were used (Chetty, 2004; Yin, 2009). Interviews ( $n=54)$ and observations $(n=12)$ served as the primary data sources. Secondary data were scanned, and 36 documents were identified as relevant and hence analysed (27 organisational documents and 9 archival documents). Data collection took place in 2012 and 2013.

The majority of the interviews (86\%) were conducted face-to-face, the remainder via telephone or video call. Interviews were conducted with senior executives, marketing managers, or research and development $(\mathrm{R} \& \mathrm{D})$ managers. In larger organisations, we interviewed several managers. The average interview duration was 48 minutes. Data collection comprised at least two interviews with representatives of each of the 10 types of CLORs, as in Gerke et al. (2015). Interviewees were primarily involved in interorganisational linkages. In the French case, the cluster manager identified key actors in the cluster. In the New Zealand case, interviewee selection relied upon the snowball method (Miles, Huberman, \& Saldaña, 2014).

The interview questions probed the CLORs' involvement in interorganisational linkages (e.g., To what extent are you linked to other CLORs?); the nature of the interorganisational linkages (e.g., How are you connected with these CLORs? Describe the relationships between your organisation and other CLORs.); motivations and intentions for involvement in interorganisational linkages (e.g., Why and how have these linkages developed? To what extent are there regular interactions?). The principal investigator transcribed all interviews. Interview 
transcripts were sent to participants for verification. Interviewees either offered amendments (SAILBRIT 56\%, SAILAUCK 41\%) or confirmed the transcripts without amendments.

The first author attended trade shows, amateur and professional sport events, product trials, professional seminars, and networking events to collect observational data. Data collected during observations included photographs, explorative interviews, advertisements, event programs, and newspaper articles. Results from observations were summarised in reports for further analysis. Observations also served as a starting point to contact interviewees.

Secondary data included organisational information and archival data. Organisational information referred to CLOR-authored presentations, brochures, catalogues, websites, Internet blogs, advertising material, and product descriptions. Archival data included third-party authored information, such as specialist journals, industry reports, and mainstream media publications. These secondary information served to identify interview candidates and initial screening of CLORs' involvement in interorganisational linkages.

\subsection{Data Analysis}

All interview transcripts, observations reports, and selected secondary data were analysed and coded using NVivo. For the first research question, a number of themes were identified deductively from the literature while additional themes appeared and were added during the coding process (Dubois \& Gadde, 2002).

The starting point for the first research question - what is the nature of interorganisational linkages in sport industry clusters - was to identify interorganisational linkages between CLORs. Interviewees referred to links with one other organisation (i.e., IOR), or to linkages with several other CLORs (i.e., ION) (Babiak, 2007; Oliver, 1990; Provan et al., 2007, Warren, 1967). Further subthemes that emerged were informal and formal both IOR and ION (Babiak, 2007; Vlaar et al., 
2006). While the level of formality in reality is surely nuanced, a dichotomous coding system provided suitable clarity and distinction. After coding analysis, we conducted frequency counts for each theme and type of source within each theme (Babiak \& Thibault, 2009). This organised the data and assisted with quotation retrieval. To ensure trustworthiness and credibility of coding results, tables of coded references were cross-checked by co-authors.

To address the second research question - how do interorganisational linkages develop in sport clusters - we conducted an inductive analysis across all data. We compared our findings with previous research on patterns for linkage creation to identify differences and similarities. Finally, to address the third research question - what are the organisational motivations for creating or joining sport clusters? - we returned to a deductive approach. We used Oliver's (1990) framework of motivational patterns as analysis scheme.

\section{Findings}

In the following sections we provide evidence that consecutively addresses the three research questions: nature of interorganisational linkages in clusters, the development process of interorganisational linkages, and motivational patterns for creating or joining them.

\subsection{Typical Nature of Interorganisational Linkages}

The analysis revealed that both IORs and IONs were prevalent amongst CLORs in both cases. IORs tended to be formalised, while IONs typically remained informal. Tables 1 and 2 provide an overview of each theme's frequency and the number and type of sources within each theme for SAILBRIT and SAILAUCK. Evidence for the different types of linkages is discussed in the following paragraphs.

Insert Table 1 about here.

Insert Table 2 about here. 
6.1.1. Formal IORs. Formal IORs between CLORs manifested themselves in various manners. One-off transactional IORs between buyer and supplier, between service provider and client, or between subcontractor and client reflect the presence of simple transactional IORs that are rooted in market mechanisms. This research, however, focuses on more complex IORs based on trust and collaboration; for example, competing core equipment manufacturers joined forces formally to secure bigger contracts because one firm alone could not have responded to the bid.

Formal IORs for other than purely economic reasons included agreements and partnerships aiming at joint innovation and R\&D. IORs emerged between a company and a university laboratory or research institute, or between a supplier and a professional or amateur sport organisation. The mechanisms through which these IORs were formalised included the commissioning of a research study, joint funding of a doctoral student, collaboration on specification sheets, or through confidentiality agreements (e.g., for joint product development). This quote illustrates how a professional sailing team provides input for innovation in determining specifies features required to improve marine equipment via specification sheets:

For five years the partnership has been quite structured. That means that every year we make a specification sheet for them with our needs, such as the type of navigation software that we like to use, the functionalities that we would like to have, or the type of interface we need (SAILBRIT, professional sailing team).

Professional and amateur sport entities maintained formal IORs with core equipment manufacturers, marine accessories, services, and systems suppliers through sponsoring agreements and for product testing purposes as one respondent indicated: "We make quite formal criteria to formalise their needs and their feedback" (SAILBRIT, marine service/consulting firm). 
Quasi government agencies and non-profits such as Chambers of Commerce, public authorities for economic development, industry associations, sport federations, or dedicated cluster governing bodies played a key role in fostering and implementing formal IORs. The cluster or industry governing bodies maintained formal IORs through funding programs or membership. For example, Eurolarge Innovation was an organisation dedicated to develop the ocean racing cluster in Brittany (Eurolarge Innovation, 2016), and NZ Marine was the industry association for the New Zealand marine industry (NZ Marine, 2016). In both cases CLORs pay a yearly fee depending on the organisation's size to benefit from the services provided.

6.1.2. Informal IORs. The data from our cases showed that informal IORs evolved from formal IORs (e.g., regular purchases from the same supplier) through long term exchanges and interactions that created affinities and built strong interpersonal relationships. The following quotation illustrates this with an example of an initially pure contractual relationship that has evolved towards informal mutual exchanges and aid:

Yes, indeed with certain clients it happens that we discuss issues equally outside of purely commercial relationships and then if there are problems to solve, we direct each other to people that we know and that can be of help. Some of my clients will also recommend my services to people that are potentially interested. That is quite possible (SAILBRIT, marine service/consulting firm).

Our data revealed that informal exchange was possible through geographical and social proximity, and high frequency of exchange and interaction. This proximity permitted unscheduled and random encounters that fostered the formation of informal IORs, which is highlighted as a major advantage of the sailing cluster as evidenced by the following quotation: 
I think that the main advantage of having this grouping of competences in the territory, which is not very big, is that it allows to easily discuss with people and to be able to look for competencies not too far away. It's true that this makes life easier (SAILBRIT, marine service/consulting firm).

Despite the evidence of formalised relationships, many CLORs relied heavily on the trust, social capital, and confidence in ongoing interactions. Some administrators attributed little value to formalised interorganisational linkages, especially once they become informal. The director of a marine equipment firm testifies:

I think that the contract is only a paper. It has only little value, even if we arrived at a conflict concerning an aspect in the contract, I don't think that (contract) would play such an important role (SAILBRIT, marine equipment firm).

Formalised roles and responsibilities served only as a potential safety net, yet partners in the sport clusters interacted and relied on informal exchanges and relied much less on formal contracts. In the cases studied, structural similarity, common culture, complementary management styles, and collective experience and background created mutual commitment and trust. Dyadic relationships were critical in the sailing clusters - both formal and informal in nature - to build IONs.

6.1.3. Informal ION. Our analysis uncovered strong evidence for informal IONs in both cases. The data indicated the importance of historical and socio-economic circumstances for network development in sport clusters and as such, informal IONs served to facilitate formal business exchanges. A shipyard director explains the advantages of informal linkages: It happens so much smoother when you have good working relationships [with maintenance firms, customers, the teams, suppliers]. This does not necessarily mean 
regularly meeting up and going out for lunch or dinner; it is frequent communication and the odd catch-up meeting around a table to discuss any issues or sharing of good ideas and then getting back to work (SAILAUCK, shipyard).

Many respondents discussed the importance of knowledge sharing through informal networking in the cluster. This was facilitated through a shared macro-structure of language, social ties, and a set of standards and values. One cluster member summarises this special atmosphere with the following words:

It is a family, let's say, this is the 'Silicon Valley' of sailing, here. That is why we all speak the same language, we speak about the same things. At the end of the day, even if the names of the big teams change, Groupama, Virbac, Banque Pop, etc., the people that work inside, the ones that are part of it, they are part of the family (SAILBRIT, marine service/consulting firm).

The analysis revealed two distinct constellations of informal IONs: informal IONs consisting of similar organisations and informal IONs consisting of different but complementary organisations. Informal IONs between similar CLORs were formed through informal interaction by providing expertise, market information, and support to each other. This was expressed by one interviewee referring to other consulting firms offering similar services when he stated, "I see that more like an exchange between these people and like a primordial source of information because otherwise I would never have had access to this information." (SAILBRIT, marine service/consulting firm).

Informal IONs amongst complementary organisations were formed through interactions between different CLORs that were originally linked through market mechanisms. Their interactions evolved and then exceeded formal agreements through interpersonal trust, mutual 
respect, citizenship, and long-standing knowledge of each other. These former business partners developed interlinked informal IORs and even IONs once the formal IOR activities had ceased. Informal IONs between heterogeneous CLORs emerged when ocean racing teams prepared for important competitions. Professional sailing sport teams and athletes need not only physical preparation and training, but they also need to construct a race boat to compete. Various complementary skills are required for a boat-building project: shipyards, naval architects, rig and sail makers, marine equipment firms, and service/consulting firms. These actors need to work together as the boat-building project is complex. This insight is key for a boat building and racing project as highlighted in the following quotation by a rig/sail maker:

The client, and when we say the client we mean Team New Zealand, realised that it is very, important to actually engage the suppliers and make them part of the whole [development] process (SAILAUCK, rig/sail maker).

The involvement of specialised CLORs that usually worked physically close together in the shipyard or on the testing grounds was a strong lever for the creation of informal IONs. This might be a specificity of sport clusters as the linking element were the professional sport teams. Sport athletes and teams are organised in teams or clubs which makes them easier to identify, target, and involve in the development process than individual customers.

Social bonds such as family ties or friendships fostered the creation of informal IONs between CLORs: "You find that a lot of people know each other at a personal level" (SAILAUCK, governing body). Informal IONs provided access to external competences, capabilities, and knowledge without entering in formal relationships, for instance a marine equipment firm representative (SAILBRIT) stated: "It is about working your network and making the networking function." A rig/sail maker (SAILBRIT) explained: "I think that it is very 
interesting for the smaller firms to be able to join us when we work and research because we have a technical development that the others do not have."

Continuous collaboration aiming at a common goal - constructing a fast and safe ocean racing boat - created a temporary special atmosphere and environment characterised by a concentration of diverse and in-depth sailing expertise. This was described by a sail maker in SAILAUCK as “A big library... It's just a continuous cycle of building of knowledge. It's quite a unique sort of environment." Informal interorganisational exchange created IONs in a boatbuilding project. Staff rotation meaning that an employee changes the company within the cluster was common amongst CLORs. This facilitated informal network building and knowledge diffusion in the sailing clusters through both knowledge sharing (i.e., intended) and knowledge spillovers (i.e., unintended). Spatial proximity of organisations permitted informal face-to-face meetings and the development of cooperation and collaboration without the need for formalisation. The marine governing body in Auckland claims:

Fifty percent of the gain is actually the informal connections that they make with other companies. So, it's a huge value, meeting companies that otherwise they wouldn't or in an environment that is conducive for them to talk about their problems or opportunities with competitors or maybe complementary companies (SAILAUCK, governing body).

A unique characteristic of informal IONs in the sailing clusters was the trickle-down effect of knowledge, information, skill, and technology between different professional and amateur sport organisations: "I never really saw or saw very little that the other boats were using things that they would have got from the America's Cup or the Around-the-world-race. I didn't see other boats doing that, other than us" (SAILAUCK, rig/sail maker). The physical closeness between amateur and professional sport organisations, and the specialised systems, accessory, 
and services suppliers permitted knowledge transfer amongst different CLORs with minimal transaction costs. This process was facilitated through cross-functional roles of key persons in companies, professional or amateur sport organisations, and governing bodies, and ultimately created informal IONs between profit and non-profit organisations. Those were maintained through interpersonal relationships that had emerged over time, even when cross-functional assignments had come to an end.

6.1.4. Formal ION. One type of formal IONs were membership-based governing bodies. There was a cluster governing body for ocean racing technology in SAILBRIT (Eurolarge Innovation) which was a formalised ION of around 110 firms and related institutions. Smaller formal IONs formed amongst the members to find solutions for shared problems and to share investment costs. A marine service firm in SAILBRIT created a shared online communication and information platform in collaboration with marine service providers, equipment suppliers, and customers. Other firms shared the cost for a hull maintenance and cleaning facility. The starting point for these formal IONs was often the cluster governing body. On a regular basis there were formal opportunities to meet and exchange with other CLORs during industry events, seminars, workshops, and exhibitions:

[It is very important that] the firms know each other and that there is regularly room where they can meet in an informal way around some seminars and interprofessional encounters, etc. (SAILBRIT, education/research institute).

In contrast, CLORs in SAILAUCK could not rely on a dedicated sailing cluster governing body and therefore had fewer formal IONs. One example was a formal ION to defend the CLORs' interests in access to waterfront based industrial land towards the city council. Another was the creation of a training program for professions in the marine industry. 


\subsubsection{Differences and Similarities of Interorganisational Linkages across Cases.}

SAILBRIT and SAILAUCK provided similar evidence for the strong prevalence of formal IORs and informal IONs, and weaker evidence for informal IORs. The main difference was the prevalence of formal IONs in SAILBRIT through a formalised cluster governing body dedicated to the ocean sailing industry and subsequent smaller formal IONs. There was no equivalent governing body for SAILAUCK, though the marine industry association is worth acknowledging.

In contrast to SAILBRIT, SAILAUCK functioned as a self-governed system. This may be due to cultural differences and a different perception of the role of the state in the economy. Similar results as in SAILBRIT were found in other French cluster studies. French companies are willing to accept state intervention for economic development (Berthinier-Poncet, 2013; Bocquet, Brion, \& Mothe, 2013). The cluster governing body in SAILBRIT was set up and funded mainly by local state authorities (top-down) but with strong consultation of cluster members (bottom-up). In SAILAUCK, the marine industry association was only to a minor extent funded by public money; instead, a private initiative of industry and companies delivered most of the funding (bottom-up; Viederyte, 2013). These different starting points influenced CLORs' attitudes, commitment, and willingness to invest time or money in the formal ION of the cluster. More active commitment to the formal ION as a governance structure is evident in SAILBRIT, while SAILAUCK members seem to rely on relational governance in an autonomous system.

\subsection{Developmental Processes of Interorganisational Linkages}

The typical development cycle of different interorganisational linkages from formal IOR, to informal IOR, to informal ION, to formal ION is depicted in Figure 1. This pattern was evident in both sailing clusters, however only SAILBRIT reached-the fourth stage (formal ION).

Insert Figure 1 about here. 
Formal IORs turned into informal IORs, even though they were initially purely economically-driven linkages. Informal IORs between complementary firms appeared to develop from IORs rooted in market mechanisms. Individuals in CLORs that had business IORs or other formal IORs over a longer period of time started to get to know each other very well. This resulted in the creation of informal IORs that then evolved into a large informal ION through the multiplication of IORs in a geographical and social proximate environment. This phenomenon was facilitated through parallel involvement of individuals in several CLORs and led to smoother interactions, less "red tape" and paperwork and longer lasting relationships:

I was a Chairman in the Olympic Committee, that was a very formal role but there are also a lot of informal roles where people in those organisations will ring us up for advice. I am not anymore in any of those roles but we still communicate a lot with them, and that has nothing to do with my company (SAILAUCK, shipyard).

In the case of SAILBRIT, an informal ION developed into a formal ION, the cluster governing body. This institution provided a new platform for the development of formal IORs. The cluster governing body was a platform and intermediary to link potential buyers and suppliers in the cluster. At the same time CLORs made informal contacts during events and via the network of the cluster governing body. The fourth stage, a formalised interorganisational network dedicated to the sport cluster, did not exist in SAILAUCK.

Understanding the structure and nature of these linkages helps uncover features of their configuration, interaction, and exchange norms. Gleaning insights into the motivations for organisations to engage in linkages in the cluster aids in comprehending the impetus and rationale for engaging at all in a cluster.

\subsection{Motivational Patterns for Interorganisational Linkages}


Motivational patterns suggested by Oliver (1990) were applied in the context of the sailing clusters. The results are illustrated in Table 3 and explained in the paragraphs below.

Insert Table 3 about here

Asymmetry was an antecedent for formal ION formation. For example joining a governing body was sometimes driven by the motive of asymmetry. The work of the marine industry association in SAILAUCK was organised in committees. The firms that were involved in these committees could exercise influence in this specific domain which impacted all member organisations that were concerned by the specific topic. However, joining the cluster governing body in SAILBRIT meant also gaining access to knowledge and eventually technology of other CLORs since the governing body organised knowledge-sharing events. CLORs that joined an industry or cluster governing body risked losing control of the shared resources.

Reciprocity was a motive for the formation of informal IOR. CLORs developed informal IOR to other CLOR's to access and exchange knowledge and resources bases:

I think that it is very interesting for the small companies to be able to join us in our work because we have capacities in terms of calculations, technical development, and technology that others do not have. So in associating themselves with us they have the possibility to develop themselves as well (SAILBRIT, rig/sail maker).

Reciprocal motives for linkage formation primarily aimed at establishing collaborative advantage and included for example collaborations for research and development, product testing, sponsoring, informal information and knowledge transfer, and collective promotion at trade shows or sport events. IORs based on reciprocity often led to the development of informal IONs. In a network perspective reciprocity becomes a more abstract phenomenon where 
contributions to the network do not necessitate direct compensation in return. A marine service provider from SAILAUCK referred to an ION in terms of joint commercialisation: "So it's a combined effort, people work very well together. I think all the players understand that combined as a group you are better to go to the world and you create more business as a combined group then you going individually." Another example is cooperation in product development: "We were talking about a helm provider and a systems provider working more closely together. We both are able to concentrate on the best things that we can do ourselves and feed ideas" (SAILAUCK, marine equipment firm). As shown in Table 3, reciprocity occurs as motive for all types of linkages (i.e., formal and informal IOR and ION) and hence is the most evident motivational pattern for creating or joining interorganisational linkages in the investigated sport clusters.

Necessity as motivational pattern resulted mostly in formal IOR, which led in some cases to formal ION. For example, necessity was reflected in the formal ION that was formed with the creation of the cluster governing body in SAILBRIT. There were three different public authorities that jointly funded the cluster governing body for the local ocean racing industry. The cluster governing body had necessarily close formal IORs to these governing bodies and depended on them for future funding. However, CLORs that had joined the cluster governing body were also a funding source through membership fees. Public authorities would offer certain funding possibilities only to consortia or partnerships of CLORs and hence encourage formation of linkages. Necessity was also evident as a motive for formal IORs because certain CLORs depended on clients or suppliers to run their activity. For example, shipyards in SAILBRIT entered formal IORs to respond to a larger order of boat hulls that otherwise neither of them could have fulfilled alone. The regulations of the tender required the shipyards to work together. 
Efficiency as motivational pattern to create or join interorganisational linkages led in the first step to the development of mostly informal IOR between CLORs with interdependencies, but these added up quickly to informal ION. Efficiency as motive was evident for example in larger boat-building projects. Due to the close cooperation and spatial proximity of different firms on the boat construction site, knowledge and information exchanges were more efficient; better solutions at the intersections of different parts (e.g., sail and mast) were found; and collaborative synergies were optimised through direct face-to-face meetings and communication. Firms that were involved in boat-building projects, worked closely together over a longer period of time which increased efficiency through better mutual understanding:

I think part of the reason why Team New Zealand has been a successful team over the years to some degree is because we are one of the first to realise that you should not just treat all the components that go onto the boat as separate entities. They all affect each other (SAILAUCK, shipyard).

Legitimacy motives led primarily to formal ION formation. For example, CLORs joined the cluster governing body and participated in collective actions in the quest for legitimacy (e.g., through collective participation in trade shows). External pressures driving firms to join the cluster governing body were primarily economic but also social. Firms in SAILBRIT joined the cluster governing body in order to be associated more obviously with ocean racing as an established sport and industry. This provided them with an attractive image and could serve as a showcase to attract new clients, even from other sectors than the ocean racing sector. The motive of legitimacy was less evident in the SAILAUCK case as there was no dedicated cluster governing body for the ocean racing industry. 
Stability as motivational patterns to join interorganisational linkages was mostly evident in informal IORs, as they served mainly as source of information and reassurance. Stability was the motive for those CLORs that entered informal IORs primarily to have access to information. These relationships tended to be based on trust and reliance between CLORs that had established a long-term relationship. Informal IORs served as source of expertise, market information, new knowledge, and security for anticipated changes. Informal IORs assured access to information which might be crucial to the survival of the mostly small- and medium-sized enterprises (SMEs) in the sport industry.

\section{Discussion}

The majority of CLORs were comprised of private SMEs that had formal IORs with local customers or suppliers. The clusters included not only firms but also governing bodies, universities, research institutes, and amateur or professional sport organisations (Gerke et al., 2015). Firms developed not only formal IORs with other companies but also with professional and amateur sport organisations. Shipyards, marine equipment firms, rig/sail makers, marine service firms, media/communication firms, and naval architects had either informal or both informal and formal IORs with professional sport organisations, occasionally with amateur sport clubs, but also with governing bodies and research/ educations institutes.

Informal IORs developed via formal IOR through regular social interaction and exchanges which created affinities and interpersonal relationships. Formal IORs between complementary CLORs tended to lead to informal IORs due to frequent interaction facilitated by geographical and social proximity (Capo-Vicedo et al., 2008). Informal IORs between similar sometimes competing firms developed mostly from interpersonal linkages through family and friends (Chetty \& Agndal, 2008). A congruent understanding of identity in relation to others (i.e., 
congruent sense making) and psychological contracts amongst the involved parties contributed to the establishment of IORs (Ring \& Van De Ven, 1994). Formalisation of IORs was not valued as important because personal relationships and informal psychological contracts substituted or complemented formal IORs. Conditions for linkage development were trust and a shared macrostructure through a common language, social ties, and a set of standard and values (Gomes \& Hurmelinna-Laukkanen, 2013). These findings improve the understanding of cross-sector linkages in complex environments including for-profit, non-profit, public, and governing organisations by determining the nature of interorganisational linkages and their developmental process (Babiak \& Thibault, 2009; Misener \& Doherty, 2013, Shilbury, 2000).

IORs tend to be formalised while IONs remained informal in nature. As ocean racing competitions usually take several years of preparation, teams prepare sailors and the boat construction over two to three years in advance. There are a number of formal IORs between the firms contributing to the boat-building project. In addition to the formal boat-building project with numerous contractual IORs, informal IORs emerge that build up to an informal ION between the involved parties through family bonds, friendships, informal exchanges, and joint practices of sailing. The existence of formal IORs and informal IONs in the boat-building project mutually influence and reinforce each other.

The findings show that formal IORs were often a starting point from which to develop informal IORs due to frequent direct contact and exchanges. The involvement of the same organisation in various informal IORs in a geographical and social proximate environment results in the development of informal IONs. This confirms previous research claiming that an ION is a result of several interlinked IORs (Warren, 1967) and that interorganisational linkages are not always driven by economic considerations (Granovetter, 1985; Marshall, 1920). A better 
understanding of this dynamic development of formal and informal linkages can help organisations in sport clusters to consciously develop valuable IONs.

Both sailing industry clusters were characterised by an evolutional process of formal and informal IORs and IONs. While IORs tended to be formal in the beginning, there was a recurrent pattern of formal IORs that turned into informal IORs once the formal agreement ceased. This is in contrast to what Babiak (2007) found in her study on the network of a non-profit organisation. She observed that relationships tended to start informally and become formalised once trust was established. This can be explained by limited capacity (i.e., time, human resources, financial resources, and so on) of non-profit organisations to formalise relationships from the beginning. Whereas in a sport cluster many actors are private firms that are more used to formalise relationships related to economic activities.

Informal IORs developed also from social ties like family bonds, friendships, and from practicing sports. The accumulation of informal IORs in a geographically and socially proximate area allowed cluster members to meet informally and spontaneously (Capo-Vicedo et al., 2008). This permitted the creation of informal IONs amongst CLORs based on initially informal IORs. Informal IONs provided access to economic activity and growth potential since there was mutual recommendation and sharing of contracts (i.e., subcontracting of work to direct competitors) was common in the informal IONs. Motives, therefore, were lack of internal capacity paired with the intention to keep business in the cluster rather than losing it to firms outside of the cluster. In recognition of this, different public authorities provided funds to create a cluster governing body - a formal ION in SAILBRIT. The formal cluster governing body consisted of for-profit, nonprofit, public, and governing organisations that had shared interests in developing economic activities around ocean racing. This example emphasises the role of industry associations as 
intermediaries, facilitators, and levers of IONs (Gerke et al., 2015; Watkins, Papaioannou, Mugwagwa, \& Kale, 2015).

In SAILAUCK, there was a marine industry association that focused on a larger audience and that did not provide specific services for the sailing industry. Therefore the formal ION in SAILBRIT had more relevance and importance for CLORs than in SAILAUCK. SAILBRIT is an example of formalised hierarchical form of relational governance, while the case of SAILAUCK reflects an autonomous market-like form of relational governance (Bell, Tracey, \& Heide, 2009; Provan \& Kenis, 2008; von Corswant, 2005).

Linkages formed because organisational goals were either congruent (e.g., build a fast boat in the boat-building projects) or complementary (e.g., using the image of ocean racing teams for marketing purposes while the ocean racing benefits from the company's expertise). From the six determinants for IOR development suggested by Oliver (1990), the most evident motive for joining or creating IORs or IONs - formal and informal - was reciprocity. Reciprocity - the pursuit of coordination, cooperation, and collaboration in IORs - as a motive was evident in IORs and IONs formed for research collaborations, in joint bids for funding or tenders, in reciprocal informal exchange of knowledge and information, in joint presentations at trade shows or web sites, and in joint approaches to problem solutions during boat building projects. These findings show that relational governance dominates in the studied sport clusters (Babiak, 2007).

These findings are interesting in light of Babiak's (2007) claims concerning motives for organisations to join cross-sectoral IORs where she emphasised that corporate managers' personal interests, values, or beliefs led to motives for developing IORs among non-profit sport organisations. While Babiak (2007) concentrated primarily on IORs, this study also investigated IONs. An ION consists of several connected IORs which have the potential to lead to anonymity 
and a loss of control over any resources that are shared within the ION. In the sailing cluster one CLOR might share knowledge with another CLOR but then loses control over the further dissemination of its knowledge. This creates interdependencies between organisations and might lead to companies refraining from engaging in IONs (Gadde et al., 2003). On the other hand, interdependencies due to complementarity can lead to more resilience regarding external shocks due to mutual support resulting from interdependencies (Boschma, 2015).

Asymmetry was only evident as a motive for formal ION development, as cluster members sought to be able to exercise influence over other CLORs in collective projects or through taking ownership of shared resources. The necessity motive for IONs was linked to the dependence on founding partners of the cluster governing body and their funding (Babiak, 2007). Legitimacy motives for IOR formation were comparable to reasons for those of trade and industry associations (e.g., enhance CLORs’ image collectively) or lobbying groups (e. g., increase cluster visibility towards public authorities) (Oliver, 1990). The affiliation of CLORs to a cluster governing was attractive because it helped to improve CLORs' image and their marketing and communication activities.

The stability motive for organisations was associated with informal IONs. Social integration in the industry and the psychological support from other firms in the same industry sector with similar beliefs, objectives, and problems provided members with perceived and some real security. Finally efficiency motives were evident in informal IONs of boat-building projects. The close and direct cooperation on a shared physical site - the boat yard - provided easier and more efficient means of meetings and exchange. This resulted in more efficient problem-solving and the harmonisation of interrelated processes.

\section{Conclusions}


This research extends knowledge on IOR literature in sport management. The theoretical contributions are (a) illustrating the multitude and variety of interorganisational linkages in crosssectoral sport contexts; (b) identifying and explaining a circular development process of different types of interorganisational linkages; and (c) identifying different motivational patterns as antecedents for the formation of different types of interorganisational linkages. Furthermore, we contribute to general cluster literature by providing insights on the underlying factors of the sustainability of interorganisational linkages that are somewhat crucial for the sustainability of clusters (Li, Veliyath, \& Tan, 2013).

We provide a nuanced perspective on the variety of interorganisational linkages in the cross-sectoral context of sport clusters. To date, researchers have focused on either dyadic IORs (Babiak, 2007; Babiak \& Thibault, 2009; Cousens et al., 2006; Dana \& Granata, 2013; Oliver, 1990; Ring \& Van De Ven, 1994; Vlaar et al., 2006), or on IONs (Camagni, 1993; Capo-Vicedo et al., 2008; Chetty \& Agndal, 2008; Provan et al., 2007). We suggest a clearer distinction and consequently a clearer terminology and understanding of interorganisational linkages and their nuanced differences by distinguishing formal IOR, informal IOR, formal ION, and informal ION. While IORs tend to be formalised in sport clusters, IONs were more likely to remain informal in nature. Formal IORs tend to develop into informal IORs. Over time an informal ION emerges. The synergy potential of the informal ION encourages the institutionalisation of the ION into a formal governing body (formal ION). The development process of interorganisational linkages and consequently determinants that favour the development of interorganisational linkages have been studied from various perspectives. IOR development can be based on interpersonal relationships (Chetty \& Agndal, 2008), and can be driven by specific motivational patterns (Oliver, 1990). Essential ingredients for development and longevity include congruent 
sensemaking and psychological contracts (Ring \& Van De Ven, 1994). We complement previous research on cross-sectoral IORs (Babiak, 2007; Babiak \& Thibault, 2009) by focusing on a crosssectoral empirical context dominated by SMEs - sailing clusters. We propose a circular framework (Figure 1) that highlights the perpetuity and renaissance of IOR and ION development. Furthermore, our data suggest that reciprocity was the main motive for joining or developing interorganisational linkages. In studying motives of sport clusters, we provide insights of central motives reported by organisations for joining an IOR or ION in a highly competitive environment.

The findings of this research provide practical insight for managers of interorganisational linkages in cross-sectoral contexts (e.g., sport clusters). Insights about IORs and IONs reveal alternatives to purely competitive approaches for strategic management of for-profit, non-profit, and public organisations. We advance knowledge and evidence for practitioners about possibilities and motives to enter interorganisational linkages. Coordination, cooperation, or even collaboration are alternative strategies in order to engage with and manage an organisation's interactions with the external environment. We provide recommendations for managers in sport clusters and show how interaction and development of interorganisational linkages with nonprofit organisations, tertiary institutions, and sport entities benefit companies and vice versa.

Engagement in formal IORs with CLORs opens up research collaborations, sponsoring opportunities, and provides access to larger contracts or external funding through collective bids. Involvement in informal IORs with CLORs provides stability through permanent access to crucial information and knowledge that organisations could not access alone or only with difficulties via formal ways. An informal ION provides access to other CLORs' resources, which allows the new combination of a variety of resources leading to innovative solutions 
(Schumpeter, 1942). A formal ION permits CLORs to promote each other collectively and reduces costs through joint investment, economies of scale, or augmented purchasing power.

The findings from this research are limited in their generalisation to other contexts. Yin (2009) argues that literal replication of findings across similar case settings strengthens theory. While there are some differences across the two cases - primarily due to cultural differences most of the results were congruent across the two cases. The findings show that sailing industries are similar across national and cultural borders because the sport determines to some extent beliefs, values, management styles, modes of functioning, and philosophies of organisations, managers, and employees (Gomes \& Hurmelinna-Laukkanen, 2013). Another notable limitation is that this study is a cross-sectional study. We asked participants to reflect on organisational dynamics that had occurred in the past (i.e., not real time or in-situ experiences and engagements with IORs and IONs). Thus, these reflections and interpretations may be influenced by the passage of time (recent or longer term). Insights about ongoing dynamics between cluster partners could be uncovered by longitudinal studies.

Further research is recommended in three areas. First, we encourage future research to advance the conceptualisation of and distinctions between IORs and IONs, specifically as they relate to industry clusters. Second, we encourage the investigation of the development pattern of interorganisational linkages in different cultural and industrial contexts. Since our findings are only indicative and limited to one sector, it would be instructive to understand the evolutional processes of IORs and IONs in various contexts and compare them. Next, the motivation patterns related to the formation of IORs and IONs should be explored in different contexts as well. Understanding the factors influencing the formation of IORs and IONs provides insights into dynamics of interaction, and measures for evaluating the effectiveness or success of relationships 
in sport clusters. We believe that there are still many unanswered questions in terms of the motivational patterns for joining and creating IORs and IONs. A more nuanced study focusing on the underlying factors of the different motivational patterns of different CLORs regarding IOR and ION formation would allow a deeper understanding of the development process of interorganisational linkages.

\section{References}

Allen, J. T., Drane, D. D., Byon, K. K., \& Mohn, R. S. (2010). Sport as a vehicle for socialization and maintenance of cultural identity: International students attending American universities. Sport Management Review, 13(4), 421-434.

Babiak, K. (2007). Determinants of interorganizational relationships: The case of a Canadian nonprofit sport organization. Journal of Sport Management, 21(3), 338-376.

Babiak, K., \& Thibault, L. (2009). Challenges in multiple cross-sector partnerships. Nonprofit and Voluntary Sector Quarterly, 38(1), 117-143. doi: 10.1177/0899764008316054

Babiak, K., \& Willems, A. (2016). Understanding interorganizational relationships in the sport industry. From theory to practice. In R. Hoye \& M. M. Parent (Eds.), Handbook of Sport Management (pp. 273-293). Thousand Oaks, CA: Sage.

Bee, C.C., \& Kahle, L.R. (2006). Relationship marketing in sports: A functional approach. Sport Marketing Quarterly, 15(2), 101-110.

Bell, S. J., Tracey, P., \& Heide, J. B. (2009). The organization of regional clusters. Academy of Management Review, 34(4), 623-642.

Benijts, B., Lagae, W., \& Vanclooster, B. (2011). The influence of sport leagues on the businessto-business marketing of teams: The case of professional road cycling. Journal of Business and Industrial Marketing, 26(8), 602-613. 
Berthinier-Poncet, A. (2013). Gouvernance et innovation dans les clusters à la française. Revue française de gestion, 232, 119-138.

Bocquet, R., Brion, S., \& Mothe, C. (2013). Gouvernance et innovation au sein des technopôles. Le cas de Savoie Technloac. Revue française de gestion, 3(232), 101-118.

Boschma, R. (2015). Towards an evolutionary perspective on regional resilience. Regional Studies, 49(5), 733-751.

Burks, A. W. (1946). Peirce's Theory of Abduction. Philosophy of Science, 13(4), 301-306.

Camagni, R. P. (1993). Inter-firm industrial networks: The costs snd benefits of cooperative behaviour. Journal of Industry Studies, 1(1), 1-15.

Capo-Vicedo, J., Exposito-Langa, M., \& Molina-Morales, F. X. (2008). Improving SME Competitiveness Reinforcing Interorganisational Networks in Industrial Clusters. International Entrepreneurship and Management Journal, 4(2), 147-169.

Chetty, S. (2004). On the crest of a wave: The New Zealand boat-building cluster. Entrepreneurship and Small Business, 1(3/4), 313-329.

Chetty, S., \& Agndal, H. (2008). Role of inter-organizational networks and interpersonal networks in an industrial district. Regional Studies, 42(2), 175-187.

Connell, J., \& Voola, R. (2013). Knowledge integration and competitiveness: A longitudinal study of an industry cluster. Journal of Knowledge Management, 17(2), 208-225.

Cousens, L., Babiak, K., \& Bradish, C. L. (2006). Beyond sponsorship: Re-framing corporatesport relationships. Sport Management Review, 9(1), 1-23.

Cousens, L., Babiak, K., \& Slack, T. (2000). Adopting a relationship marketing paradigm: The case of the National Basketball Association. International Journal of Sports Marketing and Sponsorship, 2, 331-355. 
Dana, L.-P., \& Granata, J. (2013). Evolution de la coopétition dans un cluster: le cas de Waipara dans le secteur du vin. Journal of Small Business \& Entrepreneurship, 26(4), 429-442.

De Bosscher, V., De Knop, P., van Bottenburg, M., Shibli, S., \& Bingham, J. (2009). Explaining international sporting success: An international comparison of elite sport systems and policies in six countries. Sport Management Review, 12(3), 113-136.

Dickson, G., Arnold, T., \& Chalip, L. (2005). League expansion and interorganisational power. Sport Management Review, 8(2), 145-165.

Dickson, G., Phelps, S., \& Waugh, D. (2010). Multi-level governance in an international strategic alliance. Asia Pacific Journal of Marketing and Logistics, 22(1), 111-124.

Dubois, A., \& Araujo, L. (2007). Case research in purchasing and supply management: Opportunities and challenges. Journal of Purchasing \& Supply Management, 13(3), 170181.

Dubois, A., \& Gadde, L.-E. (2002). Systematic combining: An abductive approach to case research. Journal of Business Research, 55(7), 553-560.

Dyer, J. H., \& Singh, H. (1998). The relational view: Cooperative strategy and sources of interorganizational competitive advantage. The Academy of Management Review, 23(4), 660-679.

Eisenhardt, K. M. (1989). Building theories from case study research. The Academy of Management Review, 14(4), 532-550.

Eurolarge Innovation. (2016). The ocean racing business network. Retrieved 12 July 2016, from http://www.eurolarge.fr/the-ocean-racing-business-network/ 
Ferkins, L., Shilbury, D., \& McDonald, G. (2005). The role of the board in building strategic capability: Towards an integrated model of sport governance research. Sport Management Review, 8(3), 195-225.

Frisby, W., Thibault, L., \& Kikulis, L. (2004). The organizational dynamics of under-managed partnerships in leisure service departments. Leisure Studies, 23(2), 109-126.

Gadde, L.-E., Huemer, L., \& Håkanssoinglis, H. (2003). Strategizing in industrial networks. Industrial Marketing Management, 32(5), 357-364.

Gerke, A., Desbordes, M., \& Dickson, G. (2015). Towards a sport cluster model: The ocean racing cluster in Brittany. European Sport Management Quarterly, 5(3), 343-363.

Glass, M. R., \& Hayward, D. J. (2001). Innovation and interdependencies in the New Zealand custom boat-building industry. International Journal of Urban and Regional Research, 25(3), 571-592.

Gomes, J., \& Hurmelinna-Laukkanen, P. (2013). Behind innovation clusters: Individual, cultural, and strategic linkages. International Journal of Innovation Science, 5(2), 89-102.

Granovetter, M. (1985). Economic action and social structure: The problem of embeddedness. American Journal of Sociology, 91(3), 481-510.

Huxham, C., \& Vangen, S. (2009). Doing things collaboratively: realising the advantage or succumbing inertia? In C. Huxham \& S. Vangen (Eds.), Collaborative Governance - A New Era of Public Policy in Australia? (pp. 29-44). Australia: The Australian National University.

Inglis, S. (1997). Roles of the board in amateur sport organizations. Journal of Sport Management, 11(2), 160-176. 
Kellett, P., \& Russell, R. (2009). A comparison between mainstream and action sport industries in Australia: A case study of the skateboarding cluster. Sport Management Review, 12(2), 66-78.

Li, W., Veliyath, R., \& Tan, J. (2013). Network Characteristics and Firm Performance: An Examination of the Relationships in the Context of a Cluster. Journal of Small Business Management, 51(1), 1-22.

Macris, L. I., \& Sam, M. P. (2014). Belief, doubt, and legitimacy in a performance system: National sport organization perspectives. Journal of Sport Management, 28(5), 529-550.

Marlier, M., Lucidarme, S., Cardon, G., De Bourdeaudhuij, I., Babiak, K., \& Willem, A. (2015). Capacity building through cross-sector partnerships: A multiple case study of a sport program in disadvantaged communities in Belgium. BMC Public Health, 15(1), 1-10.

Marshall, A. (1920). Industry and Trade (3rd ed.). London: Macmillan (Original work published 1919).

Miles, M. B., Huberman, A. M., \& Saldaña, J. (2014). Qualitative data analysis. A methods sourcebook (3rd ed.). London: Sage.

Misener, K., \& Doherty, A. (2013). Understanding capacity through the processes and outcomes of interorganizational relationships in nonprofit community sport organizations. Sport Management Review, 16(2), 135-147.

NZ Marine. (2016). NZ Marine. Retrieved 12 July 2016, from http://www.nzmarine.com/

Oliver, C. (1990). Determinants of interorganizational relationships: Integration and future directions. Academy of Management Review, 15(2), 241-265.

Parker, G., \& Beedell, J. (2010). Land-based economic clusters and their sustainability: The case of the horseracing industry. Local Economy, 25(3), 220-233. 
Petry, K., Steinbach, D., \& Tokarski, W. (2004). Sport systems in the countries of the European Union: Similarities and differences. European Journal for Sport and Society, 1(1), 15-21.

Porter, M. E. (2008). Clusters and Competition. In M. E. Porter (Ed.), On Competition (pp. 213303). United States of America, Boston: Harvard Business School Corporation.

Provan, K. G., Fish, A., \& Sydow, J. (2007). Interorganizational networks at the network level: A review of the empirical literature on whole networks. Journal of Management, 33(3), 479516.

Provan, K. G., \& Kenis, P. N. (2008). Modes of governance. Journal of Public Administration Research and Theory, 18(2), 229-252.

Ring, P. S., \& Van De Ven, A. H. (1994). Developmental processes of cooperative interorganizational relationships. Academy of Management Review, 19(1), 90-118.

Sarvan, F., Durmuş, E., Köksal, C. D., Başer, G. G., Dirlik, O., Atalay, M., \& Almaz, F. (2011). Network based determinants of innovation performance in yacht building clusters. Procedia - Social and Behavioral Sciences, 24(0), 1671-1685.

Schumpeter, J. A. (1942). Capitalism, socialism and democracy. New York: Harper.

Shilbury, D. (2000). Considering future sport delivery systems. Sport Management Review, 3(2), $199-221$.

Slack, T., \& Thurston, A. (2014). The social and commercial impact of sport, the role of sport management. European Sport Management Quarterly, 14(5), 454-463.

Stewart, B., Skinner, J., \& Edwards, A. (2008). Cluster theory and competitive advantage: The Torquay surfing experience. International Journal of Sport Management and Marketing, 3(3), 201-220. 
Viederyte, R. (2013). Maritime cluster organizations: Enhancing role of maritime industry development. Procedia - Social and Behavioral Sciences, 81, 624-631.

Vlaar, P. W. L., Van den Bosch, F. A. J., \& Volberda, H. W. (2006). Coping with problems of understanding in interorganizational relationships: Using formalization as a means to make sense. Organization Studies, 27(11), 1617-1638.

von Corswant, F. (2005). Organizing interactive product development. In A. Woodside (Ed.), Managing $“$ Product Innovation (Vol. 13, pp. 1-210). Netherlands, Amsterdam: Elsevier.

Walters, G., \& Anagnostopoulos, C. (2012). Implementing corporate social responsibility through social partnerships. Business Ethics: A European Review, 21(4), 417-433.

Wäsche, H. (2015). Interorganizational cooperation in sport tourism: A social network analysis. Sport Management Review, 18, 542-554.

Wäsche, H., \& Woll, A. (2010). Regional Sports Tourism Networks: A Conceptual Framework. Journal of Sport \& Tourism, 15(3), 191-214.

Watkins, A., Papaioannou, T., Mugwagwa, J., \& Kale, D. (2015). National innovation systems and the intermediary role of industry associations in building institutional capacities for innovation in developing countries: A critical review of the literature. Research Policy, 44(8), 1407-1418.

Warren, A., \& Gibson, C. (2013). Making things in a high-dollar Australia: The case of the surfboard industry. Journal of Australian Political Economy, 71, 27-50.

Warren, R. L. (1967). The interorganizational field as a focus for investigation. Administrative Science Quarterly, 12(3), 396-419.

Yin, R. K. (2009). Case Study Research: Design and Methods (4th ed.). Los Angeles, Calif.: Sage. 
Figures

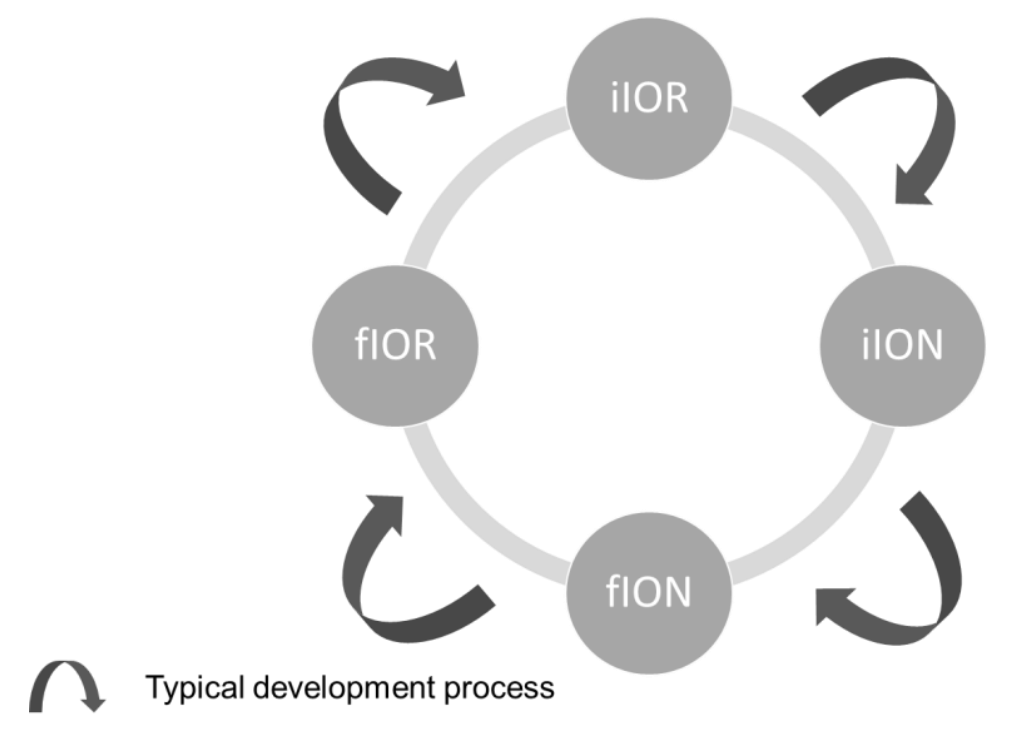

Figure 1. Development process of interorganisational linkages 


\section{Tables}

Table 1: Findings from case study

SAILBRIT

\begin{tabular}{|c|c|c|c|c|c|c|}
\hline & \multirow{2}{*}{$\begin{array}{l}\text { Number } \\
\text { of times a } \\
\text { theme } \\
\text { appears in } \\
\text { data }\end{array}$} & \multirow{2}{*}{$\begin{array}{l}\text { Number } \\
\text { of } \\
\text { sources } \\
\text { within } \\
\text { each } \\
\text { theme }\end{array}$} & \multicolumn{4}{|c|}{ Type of source } \\
\hline & & & 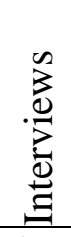 & $\begin{array}{l}\overrightarrow{0} \\
0 \\
0 \\
0\end{array}$ & $\begin{array}{l}\dot{0} \\
\Xi \\
\dot{\Xi} \\
\dot{0}\end{array}$ & 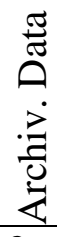 \\
\hline $\begin{array}{l}\text { Formal } \\
\text { relationships }\end{array}$ & 115 & 29 & 27 & 0 & 0 & 2 \\
\hline $\begin{array}{l}\text { Informal } \\
\text { relationships }\end{array}$ & 59 & 24 & 22 & 0 & 1 & 1 \\
\hline Formal networks & 59 & 22 & 19 & 1 & 1 & 1 \\
\hline Informal networks & 134 & 37 & 27 & 4 & 4 & 2 \\
\hline
\end{tabular}


Table 2: Findings from case study SAILAUCK

\begin{tabular}{|c|c|c|c|c|c|c|}
\hline & \multirow{2}{*}{$\begin{array}{c}\text { Number } \\
\text { of times a } \\
\text { theme } \\
\text { appears in } \\
\text { data }\end{array}$} & \multirow[b]{2}{*}{$\begin{array}{c}\text { Number } \\
\text { of } \\
\text { sources } \\
\text { within } \\
\text { each } \\
\text { theme }\end{array}$} & \multicolumn{4}{|c|}{ Type of source } \\
\hline & & & 苞 & $\begin{array}{l}\overrightarrow{0} \\
0 \\
0 \\
0\end{array}$ & $\begin{array}{l}\dot{0} \\
\stackrel{\Xi}{0} \\
\dot{00} \\
\dot{0}\end{array}$ & 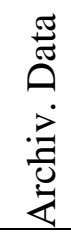 \\
\hline $\begin{array}{l}\text { Formal } \\
\text { relationships }\end{array}$ & 105 & 28 & 24 & 0 & 3 & 1 \\
\hline $\begin{array}{l}\text { Informal } \\
\text { relationships }\end{array}$ & 68 & 26 & 24 & 0 & 1 & 1 \\
\hline Formal networks & 26 & 18 & 15 & 3 & 0 & 0 \\
\hline Informal networks & 133 & 34 & 26 & 1 & 6 & 1 \\
\hline
\end{tabular}


Table 3: Motives/reasons for Interorganisational Linkages

\begin{tabular}{lll}
$\begin{array}{l}\text { Type of } \\
\text { Linkage }\end{array}$ & Motives/Reasons emerging from Data & $\begin{array}{l}\text { Motives according to Oliver } \\
(1990)\end{array}$ \\
\hline formal IOR & $\begin{array}{l}\text { commercial agreements and transactions } \\
\text { (purchase and subcontracting), research } \\
\text { collaborations, sponsoring contracts, } \\
\text { confidentiality agreements, joint bids for } \\
\text { funding or tenders }\end{array}$ & \\
& reciprocity, necessity \\
\hline informal IOR & $\begin{array}{l}\text { historically developed social ties, family } \\
\text { bonds, friendships, informal knowledge } \\
\text { and information transfer/exchange, } \\
\text { possibility to offer joint product } \\
\text { packages, access to expertise }\end{array}$ & \\
\hline formal ION & $\begin{array}{l}\text { cluster governing body/association, } \\
\text { research consortium, joint bids for } \\
\text { tenders/funding, joint stands and } \\
\text { presentation at trade shows, reduced cost } \\
\text { for investment }\end{array}$ & \\
\hline informal ION & $\begin{array}{l}\text { boat-building projects, networking } \\
\text { meetings, shared clients/markets, shared } \\
\text { problems }\end{array}$ & reciprocity, efficiency \\
\hline
\end{tabular}

IOR=interorganisational relationsh, ION=interorganisational network 